ICEM2011-590[ ]

\title{
WASTE LOADING ENHANCEMENTS FOR HANFORD LOW-ACTIVITY WASTE GLASSES
}

\author{
Albert A. Kruger, Glass Scientist \\ DOE-WTP Project Office Engineering Division \\ US Department of Energy \\ Richland, Washington USA
}

\begin{abstract}
About 50 million gallons of mixed waste is currently stored in underground tanks at The United States Department of Energy's (DOE) Hanford site in Washington state. The Hanford Tank Waste Treatment and Immobilization Plant (WTP) will provide the Office of River Protection (ORP) with a means of treating this waste by vitrification for subsequent disposal. The tank waste will be separated into low- and high-activity waste fractions, which will then be vitrified respectively into Immobilized Low Activity Waste (ILAW) and Immobilized High Level Waste (IHLW) products. The ILAW product is destined for disposal in an engineered facility at Hanford site while the IHLW product will be disposed in a national geological repository. Both waste forms must meet a variety of requirements to ensure the protection of the environment before they can be accepted for disposal.
\end{abstract}

\section{INTRODUCTION}

DOE-WTP is examining options to optimize the LAW Facility and LAW glass waste form. One option under evaluation is to enhance the waste processing rate of the vitrification plant currently under construction. It is likely that the capacity of the LAW vitrification plant can be increased incrementally by implementation of a variety of low-risk, highprobability changes, either separately or in combination. These changes include:

- Operating at the higher processing rates demonstrated at the LAW pilot melter;

- Increasing the glass pool surface area within the existing external melter envelope;

- Increasing the glass waste loading; and

- Operating the melter at a slightly higher temperature.
Some of these incremental improvements have been tested including increasing the waste loading, increasing the processing temperature, and increasing the fraction of the sulfur in the feed that is partitioned to the off-gas. These approaches successfully demonstrated increases in glass production rates and significant increases in sulfate incorporation at the nominal melter operating temperature of $1150^{\circ} \mathrm{C}$ and at slightly higher than nominal glass processing temperatures. Subsequent tests demonstrated further enhancement of glass formulations for all of the LAW waste envelopes, thereby reducing the amount of glass to be produced by the WTP for the same amount of waste processed. Subsequent testing determined the applicability of these improvements over the expected range of sodium and sulfur concentrations for Hanford LAW. This approach was then applied to an even wider range of LAW wastes types, including those with high potassium concentration. The feasibility of formulating higher waste loading glasses using $\mathrm{SnO}_{2}$ and $\mathrm{V}_{2} \mathrm{O}_{5}$ in place of $\mathrm{Fe}_{2} \mathrm{O}_{3}$ and $\mathrm{TiO}_{2}$ as glass former additives was evaluated.

\section{NOMENCLATURE}

DOE US Department of Energy

DM-10 DuraMelter-10 $\left(0.02 \mathrm{~m}^{2}\right.$ melt surface area $)$

DM-100 DuraMelter-100 $\left(0.11 \mathrm{~m}^{2}\right.$ melt surface area $)$

DM-1200 DuraMelter-1200 (1.2 $\mathrm{m}^{2}$ melt surface area)

WTP Low Level Waste Melter $10.0 \mathrm{~m}^{2}$ melt surface area

ILAW Immobilized Low-Activity Waste

IHLW Immobilized High-Level Waste

MT Metric Tonnes

ORP Office of River Protection

WTP Waste Treatment \& Immobilization Plant

The principal objective of the DOE-WTP effort is to extend the glass formulation methodology developed in the earlier 
work by development of acceptable glass compositions for two LAW waste compositions in an attempt to increase waste loading and sulfur tolerance as well as reduce refractory corrosion. The scope of this work included, the effects and potential benefits of increased magnesium concentrations were investigated in the reformulation process. Initial tests were conducted to determine the effect of magnesium on glass properties and the preferred concentrations. These objectives were accomplished through a combination of crucible-scale work and tests on the DM10 melter system. The DM10 was used for several previous tests on LAW compositions to determine the maximum feed sulfur concentrations that can be processed without forming secondary sulfate phases on the surface of the melt pool. This melter is the most efficient melter platform for screening glass compositions over a wide range of sulfate concentrations and therefore was selected for the present tests. The melter tests provide information on melter processing characteristics and off-gas data, including sulfur incorporation and partitioning.

The two waste types selected for testing, and their respective starting glass compositions

are:

(1) LAWA187 with a waste loading of $30.5 \mathrm{wt} \%$ for LAW from tank AN-105.

(2) ORPLG9 with a waste loading of $29.1 \mathrm{wt} \%$ for LAW from tank AP-101.

The objectives of the work were:

(1) Develop glass formulations that are compliant with processing and product quality requirements for the above two waste streams, that exceed previously attained waste loadings, sulfur tolerance, and are less corrosive to refractory materials.

(2) Evaluate the effect of higher $\mathrm{MgO}$ concentrations on the properties of LAW glasses formulated for tanks AN-105 and/or AP-101.

(3) Based on the results of the above evaluation and previous work for WTP and DOE-WTP, formulate higher waste loading glasses for AN-105 and AP-101.
(4) Determine the maximum feed sulfur concentrations that can be processed on the DM10 melter without the formation of secondary sulfate phases for each of the two LAW glass formulations.

(5) Develop the work scope needed to update and modify the LAW correlation algorithm using the new data on high waste loading LAW glasses developed for DOEWTP.

Results from the present work combined with previous work for DOE-WTP, show the potential for a $58 \%$ increase in average $\mathrm{Na}_{2} \mathrm{O}$ loading in Hanford LAW glasses from the WTP baseline of approximately $13 \mathrm{wt} \%$ to about $20.6 \mathrm{wt} \%$. This increase in waste loading has the potential to reduce the amount of LAW glass produced at Hanford by over 230,000 MT depending on the amount of process sodium additions. Importantly, these enhancements should be directly applicable to the planned supplemental treatment facility. Furthermore, since the approach developed by the DOE-WTP spans likely extremes in the expected LAW compositions, the results would remain relevant even if various LAW tank wastes are blended, since blending generally has the effect of affording yet further improvements in waste loadings.

\section{ACKNOWLEDGMENTS}

The author is grateful to the U.S. Department of Energy Federal Project Office for the Hanford Tank Waste Treatment and Immobilization Plant for financial support. To Professor Pavel Hrma for his unwavering encouragement and invaluable participation in demonstrating the flexibility of the joule-heated ceramic-lined melter combined with formulations of borosilicate glasses. Finally, to Professor Ian Pegg and the staff of the Vitreous State Laboratory of the Catholic University of America for their execution of all the work on scaling and pilotscale processing.

\section{REFERENCES}

Muller, I. S., Joseph, I, Matlack, K. S., Gan, H, Pegg, I. L., and Kruger A. A., Waste Loading Enhancement for Hanford ORP LAW Glasses, US DOE ORP-48578, 28 December, 2010. 